\title{
Worker Productivity, Leadership Style Relationship
}

\author{
S. Anbazhagan ${ }^{1}$, Bhargava R. Kotur ${ }^{2}$ \\ Department of Lifelong Learning, Bharathidasan University, Khajamalai Campus, Trichy, TN, India.
}

\begin{abstract}
The study investigated the work performance and the leadership styles of the workers in the Chittoor Sugar factory located at the Chittoor town of South India in order to know the correlation between the work performance and the leadership style of the workers. The study mainly concentrated on the three interesting leadership styles that are at the top, bottom and the middle of the leadership authority hierarchy, namely the autocratic, democratic and the laissez-faire leadership styles. Upon study it has been found that the more productive workers are indeed inclined towards the autocratic leadership style, the least productive workers have more of the laissez-faire leadership styles and the medium productive workers are more inclined toward the democratic style.
\end{abstract}

Keywords: autocratic, democratic, laissez-faire, leadership styles, workers, worker's productivity.

\section{Introduction}

Various people described performance in various ways. Robert and Tim (1998) have described performance as an act of accomplishing or executing a given task. According to Olaniyan (1999) performance is the ability to skillfully combine the right behavior towards the achievement of stated goals and objectives.

On the other hand, leadership has been defined (Akintunde, (2001) as the process of influencing others to get the job done effectively over sustained period of time. Although there are different types of leadership styles identified in the literature, one classification that is based on the exhibition of authority broadly yields three styles of leaderships (Wiles, 1990) and these include the Autocratic, Democratic and Laissez-faire Leadership Styles (Liberman et al., 1994). In the autocratic leadership or the authoritarian leadership style, the power and decision-making reside with the leader. The leader does not delegate authority or permit subordinates to participate in policy-making (Smylie and Jack, 1990; John, 2002). In the democratic style of leadership, the group and the leader participate in the decision making. Ideas are exchanged between employees and the leader (Heenan and Bennis 1999). In laissez-faire leadership style allows complete freedom to group members and the subordinates are free to do what they like. The leader does not interfere with or participate in the course of events determined by the group (Talbert and Milbrey, 1994).

Various studies (ex: Church, 1995) on leadership have investigated the influence of the leader's (boss's) leadership style - on the followers' behavior and performance. The modern leadership theory is with the view that none of the leadership styles could yield the best results universally and depending on the situation and the followers the leader has to change his or her leadership style (Andrew, 2009). Although some leadership studies indicate mixed and ambiguous results (Graen et al., 1972; Downey et al., 1975) on the performance of the leadership styles, yet - many studies point out that some leadership styles indeed yield better performance compared to the others. Many studies point out that the autocratic leadership style is more productive compared to any other leadership style (Adepoju 1996; Bolarinwa, 2002) and under a democratic leader although workers perform well their output but not the optimal (Adeyemi, 2011) and the laissez-faire leadership yields the minimal results (Oluwatoyin, 2003).

The work of (Bhargava and Anbazagan, 2014) studied the influence of the leadership styles of the employees on the self performances of the workers and it proved that the workers exhibiting the autocratic leadership style indeed give better results compared to the others.

But, in contrary to those studies the aim of this study is to investigate the relationship between the performance of the workers and their leadership styles. Some of the research studies on the concept are brought into light in the next section.

\section{Related Literature}

Performance has been defined to be (Mayer, Salovey and Caruso, 2000) the amount of a person's work achievement after getting exerted effort. Robert and Tim (1998) have described performance as an act of accomplishing or executing a given task

Akintunde (2001) defined leadership as the process of influencing others to get the job done effectively over sustained period of time. McNamara (2009) simply defined leadership as establishing direction and influencing others to follow that direction. In order to be effective, several authors (Vannier and Gallahue, 2008) postulated that leaders should posses and demonstrate certain leadership traits and Wuest and Bucher (2009) are 
also with the same opinion. This implies that the effectiveness and efficiency are the result of the leadership traits in an employee. Horine (2009) and Akintunde (2001) are also with the same opinion that the performance is the result of certain leadership traits. There are many are studies which confirm the existence of a relationship between leadership style and performance, although the correlation between leadership styles and the performance is not as straightforward as it might appear.

Studies on leadership styles and performance found out that there are positives associations, negatives associations and no linkages between these two variables. The studies of (Adepoju 1996; Bolarinwa, 2002) also indicate significant relationship between autocratic style of leadership and the job performance of teachers in certain situations. Another work by the researcher Church (1995) confirmed that leadership style of managers at the workplace directly affects worker's performance. Yousef (2000) made a review of the studies and came to the conclusion that the results are "not entirely consistent" and "inconsistent". Positive associations between leadership styles and performance variables were found out of the studies of the authors: Dawsan et al.(1972); Swanson and Johnson (1975); Euske et al. (1982); Euske and Jackson (1980).

Negative associations between leadership styles and performance variables were discovered by Pritchard and Karasick (1973); Sheridan and Vredenburgh (1978); Hampton et al. (1986); Yousef (2000).

Some other studies showed that there is no link between leadership styles and performance: Lowin et al. (1972); Graen et al.(1972); Downey et al.(1975); Weed et al.(1976); O'Reilly and Roberts (1978); Sheridan and Vredenburgh (1978). The studies of (Dolatabadi and Safa, 2010) on the banking sector indicate that leadership styles in fact influence the performance of the employees.

The work of [Oladipo Kolapo Sakiru et al., 2013] reveals that - there exists a significant linear relationship between worker performance and transactional leadership and no significant linear relationship between worker performance and transformational leadership. The findings of the research by [Paulus, Seta and Baron, 1996], and [Ristow, Amos and Staude, 1999] claim that worker performance is going to be characterized by high amounts of transformational leadership. The research work by [Golden and Dornheim, 1998], [Stein and Book, 2000 ] and [Yukl, 1998] indicate an optimistic relationship between the worker performance and leadership.

Contrary to the many studies that investigated the influence of the leadership styles on the performance, the aim of this study is to investigate the correlation between the performance and leadership styles of the workers. There are no quit a lot of research studies on this concept but, only a few are available on this and some of them are listed before.

\section{Problem and Objectives}

Concerning the autocratic, democratic and laissez-faire leadership styles, there is no known research work on the correlation between the worker's performance and the employee's own leadership styles, especially in the Chittoor sugar factory located at the Chittoor town of south India. Therefore, the aim of this study is to investigate and explore such relationship. Consequently, the research problem is defined as follows.

To study the correlation between the Worker's productivity and worker's Leadership Styles in the Chittoor Sugar factory, located at the Chittoor town of Andhra Pradesh, South India.

Naturally, the broad objectives of this research study could be narrowed down to: 1) finding the performance levels of the workers 2) finding the different Leadership Styles of workers 3) To study the correlation between the performance of workers and their concerned leadership Styles.

\section{Leadership Styles Studied}

The basic styles of leadership having been discussed above, for the purpose of this study, only the last three leadership styles are taken into account. The leadership styles chosen for this research study are: 1) Autocratic (authoritative) leadership style 2) Democratic leadership style and 3) Laissez-fair leadership style.

\subsection{Reasons for choosing the above styles}

The reason behind choosing the above said leadership styles for this study are discussed below:

a) The chosen leadership styles - the autocratic, democratic and laissez-faire leadership styles fall at the top, the middle and the bottom in terms of exerting authority in the spectrum of the leadership styles. The autocratic leadership style is the one that has the maximum control on the group members, exerting peak levels of authority. The sub-ordinates have nothing to share with their leader and their opinions are not cared for. Just they are followers. The laissez-fair leadership has the minimal or no authority on its group members, giving full freedom to the group. The democratic leadership comes in between these two exerting a balanced authority on its group members. It gives freedom to the group members as well controls them too.

Naturally, it is interesting to study these three leadership styles and this is one of the reasons for choosing these three leadership styles in this research study. 
b) Another reason for selecting these three styles for this study is this: According to sociology, the group psychology has an impact on all the group members too. The group members will acquire certain characteristics of the group without being aware of them.

India is a democratic country and naturally we can expect from the above sociology theory that the individuals in India will acquire the democratic characteristics more or less. Hence, it is postulated that the democratic traits should be exhibited by many people than any other leadership trait. So, the democratic leadership style is included in this study.

c) The other styles, notably transformational and transactional - have been extensively studied by various researchers in different studies throughout the world. Hence, the other leadership styles were not considered for this study.

d) The questionnaires to test all the leadership styles are very costly and are not within the affordable reach of the researcher. This too is one amongst the reasons for the researcher to confine the study only to the selected three leadership styles.

\section{Research Methodology}

This is mainly survey research. This proposed research involves empirical testing of the data collected from the workers in the factory. This research establishes nothing at all quantitatively.

\subsection{Research Universe and Sample}

This research is focused on the Sugar factory at Chittoor town in the state of Andhra Pradesh, south India and the mother tongue of the local people is Telugu, a South Indian language. The population or universe represents the entire group of units which is the focus of the study and the firm under study employs 652 employees of whom around 36 employees hold a supervisory role.

The sample size of the research comprised 127 of the 653 workers and 16 of the 36 supervisors. The sample of 127 workers at the firm, were randomly selected (chosen) by the researcher at the firm. The researcher placed no requirements on the workers while taking the samples.

\subsection{Data Collection}

Two questionnaires, one is the leadership styles assessment version and the other one is performance assessment version - were used to collect data. The leadership respondents (workers) were requested to complete the leadership questionnaire by scoring each individual question on a scale from 1 to 5 . Similarly, the performance questionnaire was given to those identified as raters of the leaders, the supervisors or managers of the employees. The rater respondents were requested to complete the questionnaire by scoring each individual question on a scale from 1 to 5 .

The leadership questionnaire was distributed to the employees by meeting them personally and especially during the time of lunch breaks of the firm. Each employee was given a time of half an hour for filling out the leadership questionnaire. The researcher collected the questionnaire personally from each employee, once it had been completed. The performance questionnaire was filled by the supervisor or manager of the worker having completed the leadership questionnaire.

While the respondents answer the questionnaire, if they find any difficulty or ambiguity the researcher attended them to solve their problem and got the needed data. Each rater was allowed a period of half an hour for the completion and return of the questionnaires.

Another important point is that, majority of the workers are not good at English language. So, both the questionnaires involved in this study were translated in to the mother tongue of the workers, the Telugu language so that to make their task easier. In this way the need data was collected from the firms by the researcher personally present with the respondents and this data collection took a period of over a month.

In order to confirm the leadership styles of the workers based on the results of the leadership questionnaires, personal interviews were conducted with employee union members and leaders. After this it has been found that, the questionnaire predictions are in compliance with the information gathered from the interviews. So, this is another proof that the leadership questionnaire data is valid and reliable.

\subsection{Employee Performance Instrument}

The second variable, employee performance, was captured and recorded using the Performance Questionnaire of the University of the Fraser Valley employee services performance appraisal questionnaire. The rating describes the employee's performance on each item and the evaluation scale has five (5) possible ratings, as follows. Each performance appraisal factors is measured using the scale of; 1-5. The relative meaning of the numbers from 5 to 1 is given as: Excellent - performance is consistently above acceptable performance levels, Good - performance is occasionally above acceptable performance levels and otherwise meets acceptable performance levels, Satisfactory - performance consistently meets acceptable performance levels, Sometimes 
unsatisfactory - performance is occasionally below acceptable performance levels but otherwise meets acceptable performance levels and Unsatisfactory - performance is consistently below acceptable performance levels.

The supervisor or manger of the respective employee who filled the leadership questionnaire should respond to this performance questionnaire, judging the performance of his/her subordinate (leader).

Following this a total scores is calculated for each employee. Then that score is calculated on the scale of five again and this final score will indicate the performance of the employee, as given in the above description. Each of the 112 workers performance appraisal scores, gathered from the performance appraisal questionnaire was analyzed using the SPSS.

\subsection{Reliability and Validity of the Performance Questionnaire}

This performance appraisal instrument is a component of the Institute, University of the Fraser Valley's larger performance management system. The performance management system embraces the firms stated values and seeks to ensure fairness, objectivity and consistency, while allowing sufficient flexibility to create the appropriate climate for positive interaction, communication and feedback regarding performance. Management of employees' performance is embedded in effective management processes and based on the following five processes: planning for performance, compacting, managing performance, measuring performance, and developing and encouraging performance.

This performance management system was designed more than ten years ago and has been continuously used through years and each employee under goes one performance appraisal a year in the respective departments of the university. The latest revision to the instrument was done in the year 2011 August. The performance appraisal instrument consists of a number of performance areas, with key performance indicators such as: job outputs, people management (including supervision and leadership); interpersonal relationships, communication skills, intra-personal relations and punctuality beyond other factors according to the website of the employee services department of the University of the Fraser Valley.

All performance management matters are documented in the employee services department of the university and this instrument has been proven to exhibit good results on the performance of the employees at the university since its inception, according to the university website.

\subsection{The Leadership Questionnaire}

Two data collection instruments were used in this research study. The Leadership Questionnaire of the Sage Publications was used to determine the leadership style and potential of the employees

The questionnaire contains 18 statements that identify and measure the key aspects of leadership behavior and each statement in the questionnaire relates to either transactional or transformational or laissezfaire leadership factors. The respondent is required to judge how frequently the behavior described in the statement is exhibited by him/her.

The Questionnaire uses a scale of 1 to 5 , with the five numbers representing the following meanings of the behavior described in the statements. The choice of ' 1 ' indicates - Strongly Disagree, The choice of ' 2 ' indicates - Disagree, The choice of ' 3 ' indicates - Neural, The choice of ' 4 ' indicates - Agree and The choice of ' 5 ' indicates - Strongly agree.

The leadership questionnaire had to be completed by the worker. In the questionnaire, the worker has to answer the questions that describe his/her own leadership style.

\subsection{Reliability and Validity of the Leadership Questionnaire}

When evaluating or formulating a specific instrument, reliability and validity are two of the most important aspects to be considered (Booth, 1995). Reliability and validity are the criteria used to assess whether the research provides a good measure (Whitelaw, 2001). Reliability refers to the dependability of a measurement instrument, that is, the extent to which the instrument yields the same results on repeated trials (Babbie and Mouton, 2001). I.e., it is concerned with the consistency of the particular instrument, while validity is concerned with systematic or consistent error. There are three fundamental methods that are accepted for assessing the reliability of a measurement scale: test-retest, internal consistency and alternative forms (Booth, 1995). The foremost ways to estimate the validity of the measurement are content validity, concurrent validity and construct validity (Booth, 1995).

The Leadership Questionnaire has been tested for reliability and validity in a number of settings, as stated in the official website of the sage publications. The reliability of the instrument has also been proven on many occasions through test-retest, internal consistency methods and alternative methods.

The Sage Publication's leadership questionnaire is also a standardized tool. It is valid and reliable and has been used extensively worldwide. It has proven to be a strong predictor of leader performance across a broad range of 
organizations. Hence it has been concluded that the chosen questionnaire was reliable and valid for use in the present research.

\subsection{Data Capturing}

Once all the questionnaires were collected by the researcher, the researcher coded the gathered data as needed for the study. These scores were then captured by the researcher into a Microsoft Excel spreadsheet for SPSS analysis. These scores were then imported into SPSS for analysis. The data analysis will be discussed in the later sections.

\subsection{SPSS Analysis}

The data was presented in a manner that allowed for easy analysis and testing using the Statistical Product and Service Solutions (SPSS). Once the data was imported into a SPSS spreadsheet, from the Microsoft Excel spread sheet, the researcher proceeded to calculate the necessary leadership scores as per the respective scoring keys provided along with the questionnaires, by the respective organizations.

The cross tabulations were derived from the SPSS tool, for the different cases as needed in the study. Once this is done statistical tests were done depending on the need of the research problem and these different tests are included in the section under analyses.

\section{Ethical Considerations}

All the ethical rules of the research participants, has been met in this research study. Bless and Higson Smith (2000), state the main rules as: a) voluntary participation b) the right to privacy c) Freedom and d) Anonymity and Confidentiality.

Even if the employees are willing, the organization might not permit for data collection. The organization concerned, though willing to permit the researcher, it might not permit in practice, fearing that the researcher might waste the valuable time of their employees, during the working hours of the organization. After all, it is not the obligation of organizations to allow the researchers to experiment on their employees!

But, luckily in the present study, the concerned firm was very favorable to the researcher allowing him to collect the data from the worker. The managers of the firm permitted to collect the data strictly for the research purposes only upon the condition that the names of the workers should not be revealed though the data might be published anonymously and this was all in accordance with the organizational policies and rules.

Another ethical point in research is that of confidentiality. This is concerned with using the collected data for the promised use only and not for some other purposes. Unlike in the case of anonymity, in confidentiality the researcher could identify the respondent based on her response, but should not reveal the data in public. The respondents must be assured that the data collected from them must be used for the intended purpose only and not for something else, that could damage them in some or the other way.

The data collected for this research didn't involve any confidential information to great degree, so luckily the researcher managed to collect the data from the workers of the firm with no difficulty.

In order not to take away the valuable time of the workers, and not to disrupt the work of the firm, as advised by the managers of the firm, the researcher visited the workers during the time of lunch breaks and collected the data with minimal possible interruption. The researcher believes that, during this research work no one was affected against the ethics of research and privacy.

\section{Response Rates}

Table 1: Population, Sample and Response Rates

\begin{tabular}{|c|c|c|}
\hline & Workers & Supervisors \\
\hline Population & 621 & 32 \\
\hline Sample & 127 & 16 \\
\hline Responses & 112 & 16 \\
\hline Response Rates & $88.2 \%$ & $100 \%$ \\
\hline $\begin{array}{c}\text { Total Rate } \\
\text { of Response }\end{array}$ & \multicolumn{2}{|c|}{$90 \%$} \\
\hline
\end{tabular}

As indicated in Table 1, of the 127 leaders (workers) surveyed in the sample, 112 completed the questionnaires and have been included in the analysis amounting to a response rate of approximately $88 \%$. Of the 16 supervisors surveyed in the sample, all of them completed the questionnaires and have been included in the analysis amounting to a response rate of approximately $100 \%$. Finally, the total sample size including leaders and their corresponding raters equals 128 employees, amounting to a total response rate of approximately $90 \%$. 


\section{Tests, Results}

This section includes the analysis and interpretations on the problem statements concerning this study. The research questions set forth for this study are to be answered based on the statistical tables and the relevant tests.

\section{Question One}

Q1 - There will be significant difference in the number of employees with their inherent leadership styles.

Table 2: Number of employees -vs- Leadership Styles $\sim$ Cross tabulation

\begin{tabular}{|c|c|c|c|c|}
\hline & \multicolumn{3}{|c|}{ Leadership styles } & \multirow{2}{*}{ Total No., } \\
\cline { 2 - 4 } & Autocia tic & democratic & $\begin{array}{c}\text { L aissez- } \\
\text { faire }\end{array}$ & of employees \\
\hline $\begin{array}{r}\text { Number of } \\
\text { employees }\end{array}$ & 12 & 70 & 30 & 112 \\
\hline
\end{tabular}

The table presented above states that among the sample studied the employees with democratic leadership traits are more (70) compared to the other two. The Laissez-faire leadership traits occupy the second place with count of 30 employees and the autocratic leadership style occupies the end position with 12 employees. From this we can conclude that there is significant variance in the leadership styles exhibited by different employees in the firm, with most of them favoring the democratic leadership style.

\section{Question Two}

Q2 - There is significant relation between the worker's performance and leadership style

Table 3: Pearson Correlations - Sig. (2-tailed)

\begin{tabular}{|c|c|c|c|c|c|}
\hline & & Performance & autocratic & Democratic & Leisezfair \\
\hline Performance & $\begin{array}{l}\text { Pearson Correlation } \\
\text { Sig. (2-tailed) } \\
\mathrm{N}\end{array}$ & & & & \\
\hline autocratic & $\begin{array}{l}\text { Pearson Correlation } \\
\text { Sig. (2-tailed) } \\
\mathrm{N}\end{array}$ & $\begin{array}{c}.215^{*} \\
.023 \\
112\end{array}$ & & & \\
\hline Democratic & $\begin{array}{l}\text { Pearson Correlation } \\
\text { Sig. (2-tailed) } \\
\mathrm{N}\end{array}$ & $\begin{array}{r}.243^{* *} \\
.010 \\
112\end{array}$ & $\begin{array}{r}.285^{* *} \\
.002 \\
112 \\
\end{array}$ & & \\
\hline Leisezfair & $\begin{array}{l}\text { Pearson Correlation } \\
\text { Sig. (2-tailed) } \\
\text { N }\end{array}$ & \begin{tabular}{r|}
.154 \\
.105 \\
112
\end{tabular} & $\begin{array}{r}.110 \\
.250 \\
112\end{array}$ & $\begin{array}{r}.280^{* *} \\
.003 \\
112\end{array}$ & \\
\hline
\end{tabular}

*. Correlation is significant at the 0.05 level (2-tailed).

**. Correlation is significant at the 0.01 level (2-tailed).

(Performance -vs- autocratic 0.05 level of significant, Performance -vs- Democratic 0.01 level of significant, Performance -vs- Laissez-faire not significant at any level)

The table 3 revels that the performance and the autocratic style are at 0.05 level of significant, performance of the workers and the democratic style are at 0.01 level of significant. Finally, the performance of the workers and the laissez-faire style of leadership are the very least significant or even no significant as the statistical results are revealing.

Along with the above test, from the below statistical tests too, the study concludes that the people with different performances indeed exhibit different leadership styles. The more a person is productive his style of 
leadership tends toward the autocratic and the least productive employees are found to incline toward the laissez-faire leadership style and the average productive employees come in between these two.

\begin{tabular}{|c|c|c|c|c|c|}
\hline & & \multicolumn{3}{|c|}{ Level of Performance } & \multirow[b]{2}{*}{ Total } \\
\hline & & Low & Medium & High & \\
\hline \multirow[t]{3}{*}{ Styles } & Autocratic & 2 & 3 & 7 & 12 \\
\hline & democratic & 16 & 22 & 32 & 70 \\
\hline & Leizez-fair & 8 & 9 & 13 & 30 \\
\hline Total & & 26 & 34 & 52 & 112 \\
\hline
\end{tabular}

\begin{tabular}{|c|c|c|c|}
\hline & Observed $\mathrm{N}$ & Expected $\mathrm{N}$ & Residual \\
\hline Autocratic & 12 & 37.3 & -25.3 \\
\hline Democratic & 70 & 37.3 & 32.7 \\
\hline Leizezfair & 30 & 37.3 & -7.3 \\
\hline Total & 112 & & \\
\hline
\end{tabular}

Table 6: Performance

\begin{tabular}{|l|r|r|r|}
\hline & Observed N & Expected N & Residual \\
\hline Low & 26 & 37.3 & -11.3 \\
Medium & 34 & 37.3 & -3.3 \\
High & 52 & 37.3 & 14.7 \\
Total & 112 & & \\
\hline
\end{tabular}

\begin{tabular}{|l|r|r|}
\hline & Table 7: Chi-square Test Statistics \\
\hline Lhi-Square & Leadership styles & Performance \\
\hline df & $47.214^{\mathrm{a}}$ & $9.500^{2}$ \\
Asymp. Sig. & 2 & 2 \\
\hline
\end{tabular}

a - 0 cells $(0 \%)$ have expected frequencies less than 5 . The minimum expected cell frequency is 37.3 . Significant at 0.01 Level

The study reveals that the - the leadership styles of the workers indeed are dependent on the employee' performance, more productive the employee is - the more the autocratic the employee is.

\section{Findings of the Study}

Based on the statistical tests and cross tabulations the findings of this research study are as follows. 1) This study states that all the three leadership styles are not equally present in the employees - inherently. The more dominant one is found to be the democratic leadership style; the autocratic style comes next and at the last place comes the laissez-faire leadership. 2) The study proves that people with different productivity levels indeed exhibit different leadership styles. 3) The best performing workers are found to exhibit the autocratic style and the least performing are found to the laissez-fair leaders and average performance is exhibited by the democratic leaders. 4) This study proves that - with increasing performance the leadership style of the worker tends more towards the autocratic style of leadership. In other words, the study implies that more productive workers are more assertive in nature and this finding on the laborers might not be true in the case of white color employees.

\section{Discussions}

The good news is that that are no contradicting findings out of this study and all the finding are in congruent with the established facts on leadership and performance. A) This study has concluded that all the inherent leadership styles are not equally present in the employees, investigated. The democratic leadership style is more dominant among the employees, the autocratic style comes next and the Laissez-faire leadership is exhibited by least number of employees. The modern psychology says that, certain traits or customs followed in 
the group or by the leaders of the group will be easily acquired by the group members. The above finding is in conformity with this sociological principal and as India a democratic country, the citizens of India will naturally get the democratic traits. Hence, it is no wonder that the employees studied in this research too, are inclined more towards the democratic style of leadership. This finding is in agreement with the findings (2010) of Gholamreza Taleghani, Davood Salmani and Ali Taatian, based on their study on the leadership styles survey in different cultures. The study of Javed Sawati, Saeed Anwar, Iqbal Majoka (2013) is also in agreement with the finding of this study. B) Another finding of this study says that - people with different productivity levels indeed exhibit different leadership styles. This is in agreement with the studies of - Golden and Dornheim (1998), Stein and Book (2000 ] and Yukl, (1998) apart from many others. C) This study proved that autocratic people indeed are more productive and this is in perfect agreement with the theories of leadership and example with the findings of the research study by Adeyemi (2010).

\section{Limitations of the Study}

Any research study will have its own limitations and this one is no exception, the limitations of this research study include: 1) only a sample is studied and not all the workers were studied in this research. 2) Only the select firm and not all other firms and industries were examined for this study. 3) The study is limited is geographically confined to a particular place. 4) Only a select few and not all leadership styles were examined in this study 5) in any research study the finance is the main financial constraint, the easily available questionnaires are used for this study. The leadership questionnaire and the performance questionnaire used in this study are the free versions available on-line. The other complex questionnaires are costly to purchase. So, the questionnaires used might have some inherent in-efficiencies. 6) Hence, the research results might not be the general results and more over these results from the workers need not be true in the case of white color employees and it needs to be researched over further.

\section{Conclusions}

The study concludes that the performances of the workers indeed are related to their leadership styles in a linear away. The best performing workers are found to exhibit the autocratic style; the least performers are found to exhibit the laissez-faire style of leadership and the average performers are inclined toward the democratic style. Thus this study proves that the performance, aggressiveness and leadership traits of the workers are indeed connected in a linear way, more the performance of a worker more is the aggressiveness and the exhibition of authority as well.

\section{References}

[1]. Adeyemi, T.O., 2004. Educational Administration An Introduction. Greenline Publishers. Ado-Ekiti.

[2]. Adeyemi, T.O. (2011), "Principals' Leadership Styles and Teachers' Job Performance in Senior Secondary Schools in Ondo State, Nigeria", Current Research Journal of Economic Theory, vol. 3, no. 3, pp. 84-92.

[3]. Adepoju, T.L., 1996. The factors militating against effective planning and implementation of educational policies in Nigeria. A paper presented at the WAEC monthly seminar, WAEC National Secretariat Yaba, Lagos, Feb. 28.

[4]. Akintunde, P. G. (2001) Administration and Organization of Agricultural Education Programmes in Nigeria. Ibadan: Yew Printers.

[5]. Andrew J. Dubrin, (2009), Leadership: Research Findings, Practice and Skills, 5 Ed, Houghton Mufiilin co., Boston, USA.

[6]. Bless. C and Higson-Smith. C (2000), Fundamentals of Social Research Methods (3ed.), Lusaka, Juta Education (Pvt) Ltd.

[7]. Bolarinwa. 2002. "Motivation and Teachers Job Performance in Secondary Schools in Lokoja Local Governemnt Area of Kogi State" An Unpublished M. Ed. Thesis University of Ado-Ekiti.

[8]. Golden, C.J. and Dornheim, L. 1998. "Development And Validation Of A Measure Of Emotional Intelligence", Personality and Individual Differences, 25: 167-177

[9]. Goldring, E.B. and F.R. Sharon, 1993. Principals of Dynamic Schools Newbury Park. Corwin, CA.

[10]. Heenan D.A. and W. Bennis, 1999. Co-leaders, The power of Great Partnership. John Wiley \& Sons, New York

[11]. Horine, L. (2009) Administration of Agricultural Education Programme USA: McGraw Hill.

[12]. Hoy, N.K. and C.G. Miskel, 1992. Educational Administration. Theory, Research and Practice. $2^{\text {nd }}$ Ed,. Randam House, New York, pp: 22.

[13]. Ibrahim, Ali S. and Al-Taneiji, Shaikah, (2013), "Principal leadership style, school performance, and principal effectiveness in Dubai schools", International Journal of Research Studies in Education, Vol. 2 , No. 1, pp. 41-54, DOI: 10.5861/ijrse.2012.86

[14]. John, C.M., 2002. Million leaders Mandate. Notebook one. Equip Publishers, America.

[15]. Liberman, A., F. Beverly and L. Alexander, 1994. A Culture in the Making: Leadership in Learner-Centred Schools. National Centre for Restructuring Education, New York.

[16]. Mayer, J.D., Salovey, P. And Caruso, D. 2000. "Emotional Intelligence Meets Traditional Standards For Intelligence", Intelligence, 27(4): 267-298.

[17]. McNamara, C. (2009) Overview of Leadership in Organization: Nut-and-Bolts Guide to Leadership and Supervision. New York: Harper and Row Publishers.

[18]. Mouton, J.S. and R.R. Black, 1994. Synergogy. San Francisco, Jossey - Base. Olaniyan, A.O., 1999. Principal Preparation, Selection and Leadership Roles, Teachers and Teaching in Nigeria. Benin Festa Press Ltd., pp: 73-88

[19]. Oladipo K. S, Daskareem V. E, Salami D.K and Mohammed A., 2013, "Relationship Between Employee Performance, Leadership Styles and Emotional Intelligence in an Organization”, Iosr Journal Of Humanities And Social Science, V. 8, No. 2, Pp.53

[20]. Paulus, P.B., Seta, C.E. and Baron, R.A. 1996. Effective Human Relations: A Guide To Peopleat Work (3rd Edition). Boston: Prentice-Hall. 
[21]. Ristow, A., Amos, T. and Staude, G. 1999. "Transformational Leadership And Organisational Effectiveness In The Administration of Cricket in South Africa

[22]. Robert, H. and H. Tim, 1998. Essential Manager's Manual. A korkling Kindersley Book. Colour Scan, Singapore

[23]. www.sagepub.com/northouseintro2e

[24]. Smylie, M.A. and W.D. Jack, 1990. Teachers leadership tension and ambiguities in organizational perspective education administration. Quarterly, 26: 235-259.

[25]. Stein, S.J. and Book, H.E. 2000. The Eq Edge: Eq And Your Success. Toronto: Stoddart Publishing.

[26]. Talbert, J.E. and W.M. Milbrey, 1994. Teacher Professionalism in Local School Contexts. Am. J. Edu., $102(2): 123-153$.

[27]. www.universityoffraservalley.com

[28]. Vannier, M. \& Gallahue, D. L. (2008). The Teaching of Agriculture in Elementary Schools. Philadelpha: London W. B. Saunder Company.

[29]. Wiles, K., 1990. Supervision For Better Schools Englewood-Cliffs. M.J. Practice-Hall, Practice Hall Inc., Jersey, pp: $329-341$

[30]. Wuest, D. A. \& Burcher, C. A. \& Burcher, C. A. (2009) Foundations of Agricultural Education . New York: McGraw-Hill Company.

[31]. Yousef D. A.,"Organizational commitment: a mediator of the relationships of leadership behavior with job satisfaction and performance in a non-western country", Journal of Managerial Psychology, Vol. 15, Issue:1 (2000): 6 -24.

[32]. Yukl G. 1998. Leadership In Organizations. Englewood Cliffs: Prentice-Hall 